\title{
Sociodemographic and Socioeconomic Factors as Determinants for the Health Related Quality of Life of Asthmatic Children and Adolescents
}

\author{
EMAN E. EBRAHIM, M.D.*; LUBNA M. FAWAZ, M.D.**; HWAYDA Y. ABDALLAH, M.Sc.*** and \\ SARAH ALI SALEH, M.D.** \\ The Family Medicine* \& Pediatrics**, Faculty of Medicine, Cairo University and Family Medicine Department, Ministry of Health ${ }^{* * *}$
}

\begin{abstract}
Background: Asthma is the most prevalent childhood chronic disease worldwide. Although health-related quality of life (HRQoL) in asthmatic children is known to be affected by the disease severity, sociodemographic factors and socioeconomic status (SES) may also play a role.

Aim of Study: To study the effect of sociodemographic and economic factors on HRQoL in asthmatic children and adolescents.

Patients and Methods: This was a cross sectional study during which 370 asthmatic child/adolescent and their parents were interviewed at Chest and allergy clinic and were asked to fill El-Gilany socio-economic status (SES) scale and the arabic version of Pediatric Asthma Quality of Life Questionnaire (PAQLQ) then the individual and the total scores were calculated.

Results: $79.5 \%$ of the participants were children less than 12 years old, $61.9 \%$ were females, $73.5 \%$ lived in rural areas, and $89.7 \%$ were of low socioeconomic class. Regarding the sociodemographic factors, there was statistical significance between the total score of Pediatric asthma quality of life questionnaire (PAQLQ) and the patient's age, residence, parents' education \& occupation ( $p$-value $<0.001)$. Regarding the SES, there was statistical significance between PAQLQ score and the family income and the total SES sore ( $p$-value $<0.001)$.

Conclusion: Socio demographic and economic status can be considered independent determinants of HRQoL in asthmatic children and adolescents.
\end{abstract}

Key Words: Bronchial asthma - Health-related quality of life - Socioeconomic status.

\section{Introduction}

BRONCHIAL asthma is the commonest chronic illness in children worldwide where $10 \%$ of children are on treatment for it. It is a public health problem

Correspondence to: Dr. Eman E. Ebrahim, E-Mail: emanelsayed@kasralainy.edu.eg that affects all countries regardless its level of development. The prevalence of asthma in different countries worldwide range from $1-18 \%$ of the population [1]. In Egypt, there were multiple studies to detect asthma prevalence in school children at different governorates, where among children at primary schools it was $6.5 \%$ [2], and in preparatory schools' children was $9.1 \%$ [3] while in secondary schools' students it was 9.6\% [4].

Nowadays, quality of life is considered one of the most important concepts in clinical practice as it leads to a change in patient's disease perception and so organizing a better comprehensive care [5]

The impact of bronchial asthma on the patient's quality of life has been discussed broadly in research as well as the clinical practice, it is even recommended to be assessed in the management plan of the asthmatic patient. It is well known that the asthmatic child has a different lifestyle regarding school absences, emergency department visits, and hospitalizations. It was found that thirty percent of the asthmatic children have limited activity, compared to the healthy child $[6,7]$.

Factors affecting HRQoL in asthmatic patients include the sociodemographic, clinical, and medical history of the patient. The identified sociodemographic factors related to the HRQoL of asthmatic adult patients were sex, age, marital status, and education [8]

The relation between the socioeconomic factors and bronchial asthma is highlighted mainly in terms of symptom severity and hospital admissions [9]. This relation is less investigated as most studies 
concentrated on symptom severity reporting that children with moderate or severe asthma have a lower HRQoL compared to those with mild asthma focusing on the relationship between the frequency and intensity of children's asthma symptoms and poor HRQoL [10,11]

Motaghi-Nejad et al., 2015 found that asthma has a negative effect on the HRQoL in $48.3 \%$ of patients [12] . Gonzalez-Barcala et al., in 2012 investigated the factors associated with a poor HRQoL and concluded determinants as obesity, female sex, age, low education, family history of asthma, smoking and home pets [13]

The impact of socioeconomic status on the quality of life of the asthmatic children is not well studied especially in children and adolescents. The low socioeconomic status in the form of low educational level, low family income or poor level of health insurance were related negatively to HRQL in a study done in 50 adult asthmatic patients [14]

The literature mentions asthma as a clinical disease and relate the quality of life in asthmatic patients with disease severity. Unfortunately, few data focus on the impact of socio-demographic and economic factors on the quality of life in patients with asthma, based on this, the aim of this work was to describe the impact of the sociodemographic and socio-economic factors on HRQoL of asthmatic children and adolescents.

\section{Patients and Methods}

Study setting: This study was conducted in the Chest and allergy outpatient clinic at Abou Elrish Pediatrics Hospital, Cairo University which although being in urban area, serves as well mothers coming from rural areas. The average number of patients attending the clinic was 300 asthmatic child per month either coming for follow-up or newly registered referred from the general pediatric clinics. The study was conducted along 6 months from May to October 2016.

Study design: This was a descriptive crosssectional study during which an intervieweradministered structured questionnaires were used to assess the socioeconomic status of the asthmatic child and the factors affecting their quality of life.

Study subjects: All asthmatic patients who came to the Chest and allergy clinic who agreed to share in the study and didn't have any exclusion criteria were included in the study. The excluded patients were those having factors that may affect their quality of life as chronic disease other than asthma or asthma exacerbation within the last two weeks. The sample size was calculated using Epi info 3, under a error of $5 \%$ and at least a power of $80 \%$, considering a workload of three days per week over a period of 6 months and on average 25 patients visiting the clinics per day, a minimal sample size of 370 child were recruited to achieve the study objectives.

Data collection tools: Two structured anonymous questionnaires were used to obtain the data from the clinic's attendees.

1-El-Gilany et al., 2012 Socio-Economic Status (SES) scale [15]: Detailed data on the socioeconomic status (SES) was collected using El-Gilany questionnaire which includes seven domains (education and cultural, family, economic, occupational, family possessions, home sanitation and health care domain) and has a total score of 84 . For each participant, a score was assigned for each item of the questionnaire, the total score was calculated and the socio-economic level was classified into low, middle and high levels depending on the quartiles of the calculated scores.

2- The Arabic version [16] of Pediatric Asthma Quality of Life Questionnaire (PAQLQ) [17]: It measures the functional problems that are most troublesome to asthmatic children and adolescent (7-17 years old). It has 23 questions in three domains (symptoms, activity limitation and emotional function). Children were asked to recall their experiences during the previous week, which is the maximum time younger children can recall their experiences. Response to each question is on a 7point scale with $7=$ no impairment and $1=$ severe impairment). The overall score is the mean of all 23 response and the individual domain scores are the means of the items in those domains and would be between 1 and 7 .

Study field work-up: The actual working period to collect the data was 3 days per week for a period of 6 months, (May to October 2016), during the working hours of Chest \& Allergy outpatient clinics from (8-2pm), with an average of 7 mother-child pairs per day.

After taking an oral consent from the mothers the content of the questionnaires was explained then the personal interview with the mothers was performed in the waiting area of the clinic for 10 to 15 minutes for completing the questionnaires.

Data analysis: All completed questionnaires were revised. Coded data was entered on the com- 
puter using the Microsoft Office Excel Program for Windows. All statistical calculations were done using computer program statistical package of social science software program, SPSS version 21. Data were statistically described in terms of mean \pm standard deviation $( \pm \mathrm{SD}$ ) for quantitative data. Number and percent for qualitative variables. Comparison between quantitative variables with two categories which were normally distributed was done using $t$-test. Comparison between qualitative variables done using chi-square test. Spearman rho correlation was used to test for linear relation between quantitative variables. $p$-value less than 0.05 was considered of statistical significance.

\section{Ethical consideration:}

The study protocol was revised and approved by the members of the Family Medicine Department at Kasr Al-Ainy Cairo University and approved by the Research and Ethical Committee of the Faculty. The approval for using the questionnaires were obtained from the authors via E-mail. Approval of the head of Chest and Allergy outpatient clinic at Abou Elrish Pediatrics hospital was also obtained. A detailed consent was obtained from all the mothers before participation in the study according to Helsinki declarations of biomedical ethics. The participating mothers were reassured about the confidentiality of any obtained information, and that the study results would be used only for the purpose of research.

\section{Results}

As shown in Table (1), most of the study participants were children (79.5\%), females (61.9\%) and living in rural areas (73.5\%). Most of the mothers were illiterate $(36.5 \%)$ and housewives $(88.6 \%)$ while most of the fathers were illiterate $(36.3 \%)$ and manual workers $(84.3 \%)$. There is a statistical significance ( $p$-value $<0.001)$ between PAQLQ total score and the following factors: Age, residence, parent's education and occupation.

Table (2) shows statistical significance as well as a reasonable correlation between PAQLQ total score and both parents' education and occupation.

Table (3) describes the socioeconomic status of the study participants and its correlation with PAQLQ total score. It shows that most of the study participants lived in families with income just meeting the expenses $(48.6 \%)$ and most of them $(89.7 \%)$ were considered of low socioeconomic status. There is statistical significance and positive correlation between PAQLQ total score and the family income as well as the socioeconomic status score.

Table (4) shows that there was a statistical significance between the 3 domains and the total score of PAQLQ from one side and the SES total score from the other side.

Table (1): Socio-demographic profile of the studied participants and its relation with total PAQLQ score.

\begin{tabular}{|c|c|c|c|c|}
\hline $\begin{array}{l}\text { Sociodemographic } \\
\text { data }\end{array}$ & $\begin{array}{l}\text { Number } \\
(n=370)\end{array}$ & Percent & $\begin{array}{c}\text { Total PAQLQ } \\
\text { Mean } \pm \text { SD }\end{array}$ & $\begin{array}{c}p- \\
\text { value }\end{array}$ \\
\hline \multicolumn{5}{|l|}{ Age: } \\
\hline Child $(7-<12$ years $)$ & 294 & 79.5 & $101.11 \pm 23.91$ & \multirow[t]{2}{*}{$<0.001$} \\
\hline Adolescent (12-17) & 76 & 20.5 & $114.34 \pm 24.54$ & \\
\hline \multicolumn{5}{|l|}{ Gender: } \\
\hline Male & 141 & 38.1 & $102.13 \pm 24.28$ & \multirow[t]{2}{*}{0.075} \\
\hline Female & 229 & 61.9 & $106.66 \pm 24.95$ & \\
\hline \multicolumn{5}{|l|}{ Residency: } \\
\hline Rural & 273 & 73.5 & $97.5 \pm 22.2$ & \multirow[t]{2}{*}{$<0.001$} \\
\hline Urban & 97 & 26.5 & $118 \pm 22.9$ & \\
\hline \multicolumn{5}{|l|}{ Maternal education: } \\
\hline Illiterate & 135 & 36.5 & $89.8 \pm 17.8$ & \multirow[t]{3}{*}{$<0.001$} \\
\hline Primary & 105 & 28.4 & $111.5 \pm 22.8$ & \\
\hline Higher & 130 & 35.1 & $132.4 \pm 25.0$ & \\
\hline \multicolumn{5}{|l|}{ Paternal education: } \\
\hline Illiterate & 134 & 36.3 & $94.1 \pm 20.8$ & \multirow[t]{3}{*}{$<0.001$} \\
\hline Primary & 111 & 29.8 & $107.8 \pm 23.5$ & \\
\hline Higher & 125 & 33.9 & $135.2 \pm 23.5$ & \\
\hline \multicolumn{5}{|l|}{ Maternal occupation: } \\
\hline Housewife & 328 & 88.6 & $101.6 \pm 23.9$ & \multirow[t]{2}{*}{$<0.001$} \\
\hline Working & 42 & 11.4 & $124.7 \pm 19.7$ & \\
\hline \multicolumn{5}{|l|}{ Paternal occupation: } \\
\hline Not-working & 9 & 2.4 & $72.1 \pm 10.9$ & \multirow[t]{3}{*}{$<0.001$} \\
\hline Manual Worker & 312 & 84.3 & $107.2 \pm 23.8$ & \\
\hline Professional & 49 & 13.3 & $129.4 \pm 25.5$ & \\
\hline
\end{tabular}

Table (2): Correlation between PAQLQ and parent's education \& occupation.

\begin{tabular}{lllll}
\hline & \multicolumn{2}{c}{ Education } & \multicolumn{2}{c}{ Occupation } \\
\cline { 2 - 5 } Domain & Father & Mother & Father & Mother \\
\hline Activity: & & & & \\
$\quad$ Correlation coefficient & $.434^{* *}$ & $.515^{* *}$ & $.320^{* *}$ & $.261^{* *}$ \\
$\quad$ Sig (2 tailed) & .000 & .000 & .000 & .000 \\
& & & & \\
Symptoms: & & & & \\
$\quad$ Correlation coefficient & $.421^{* *}$ & $.510^{* *}$ & $.332^{* *}$ & $.240^{* *}$ \\
$\quad$ Sig (2 tailed) & .000 & .000 & .000 & .000 \\
Emotions: & & & & \\
$\quad$ Correlation coefficient & $.429 * *$ & $.514^{* *}$ & $.318^{* *}$ & $.246^{* *}$ \\
$\quad$ Sig (2 tailed) & .000 & .000 & .000 & .000 \\
$\quad$ Total PAQLQ: & & & & \\
$\quad$ Correlation coefficient & $.434^{* *}$ & $.520^{* *}$ & $.334^{* *}$ & $.252^{* *}$ \\
$\quad$ Sig (2 tailed) & .000 & .000 & .000 & .000 \\
\hline
\end{tabular}


Table (3): Socio-economic status of the study participants and its correlation with the total PAQLQ score.

\begin{tabular}{lcccc}
\hline $\begin{array}{l}\text { Socioeconomic } \\
\text { data }\end{array}$ & $\begin{array}{c}\text { Number } \\
(\mathrm{n}=370)\end{array}$ & Percent & $\begin{array}{c}\text { Correlation } \\
\text { coefficient } \\
\text { PAQLQ }\end{array}$ & $\begin{array}{c}p \text { - } \\
\text { value }\end{array}$ \\
\hline $\begin{array}{l}\text { Family income: } \\
\text { Just meet expenses }\end{array}$ & 180 & 48.6 & 0.286 & 0.001 \\
$\quad \begin{array}{l}\text { Meet expenses }+ \\
\text { emergencies }\end{array}$ & 172 & 46.5 & & \\
$\quad$ Able to save & 18 & 4.9 & & \\
Crowding index: & & & & \\
$\quad>1$ person/room & 361 & 97.6 & -0.009 & 0.864 \\
$\quad$ 19 1 person/room & 9 & 0.4 & & \\
Socioeconomic status: & & & & \\
$\quad$ Low (<42) & 32 & 89.7 & 0.526 & \\
$\quad$ Middle (43-63) & 38 & 10.3 & & \\
$\quad$ High (64-84) & 0 & 0 & & \\
\hline
\end{tabular}

Table (4): Comparison between Total SES and PAQLQ (individual and total scores).

\begin{tabular}{llllll}
\hline \multirow{2}{*}{ Domain } & \multicolumn{4}{c}{ SES classification } & \multirow{2}{c}{\begin{tabular}{c}
$p$ - \\
\cline { 2 - 5 }
\end{tabular}} \\
\cline { 2 - 5 } & \multicolumn{2}{c}{ Low } & \multicolumn{2}{c}{ Middle } & \\
\cline { 2 - 5 } & Mean & SD & Mean & SD & \\
\hline Activity & 21.65 & 5.12 & 27.89 & 4.67 & $<0.001$ \\
Symptoms & 43.78 & 10.21 & 55.03 & 8.92 & $<0.001$ \\
Emotion & 35.67 & 8.41 & 44.76 & 7.31 & $<0.001$ \\
\hline Total PAQLQ & 101.1 & 23.54 & 127.68 & 20.62 & $<0.001$ \\
\hline
\end{tabular}

\section{Discussion}

The effect of HRQoL on chronic diseases as bronchial asthma can focus on disease threats and guide to choose an appropriate way of therapy that help the patient to comply with treatment for better disease control. HRQoL thus play a valuable role in implementing comprehensive care for specific patients as children and adolescents. So, it becomes important to indicate factors relevant to the assessment of HRQoL of the asthmatic patients as sociodemographic and economic factors.

In the present study there is significant correlation between the patient's age and the quality of life. This is in concordance with a study done by Miadich, et al., 2015 [18] where they found in their study that was conducted on 192 asthmatic children between 5 and 12 years old that older children have a drop in their HRQoL and explained that this may be due to increased asthma severity in older ages.

The current study showed that there is no association between the gender and the quality of life in concordance with Matsunaga et al., 2015 [19] who found in their study that was done on 100 asthmatic child and adolescent that gender has no effect on the HRQol of the participant, this finding may be due to most of our sample size are children $(7-13 y)$ which explain why there is no gender difference.

In our study, there is statistical significance between residency and PAQLQ total score in contrast to Al-Gewely et al., 2013 [20] who observed in their study that was conducted on 140 asthmatic children that residence had no effect on HRQoL. This can be explained by the fact that living in urban areas will give a better opportunity for medical care access and better disease control and thus better quality of life.

Our study shows that parent's education is strongly correlated with the all the domains and the total score of PAQLQ. This is in line with most researches that agree on the influence of education on HRQoL in asthmatic patients. As an example, a study by Uchmanowicz et al., 2016 [8] showed significance between education and symptoms \& activity limitations domains. Ferreira et al., 2010 [21] confirmed this result and added that quality of life scores is higher in patients with higher educational level, proper family income and living in urban areas. A high parent's education will help in raising the child awareness of his illness leading to better coping with the burden of the disease and a better quality of life.

In the present study, most of the participants were of low socioeconomic status (89.7\%). In contrast to Norbäck, et al., 2013 [22] who concluded in their study that high socioeconomic class can be one of the risk factors for asthma in pre-school Chinese children, they explained this by more exposure to air pollution and dampness. This difference between both studies is mostly attributed to the fact that most patients who already came to Kasr Al Ainy Hospital are already of low SES.

In our study we found that the family income is strongly correlated to quality of life, in contrast to Al-Gewely et al., 2013 [20]. It is explained by a better income means affording better access to health care facilities and better quality of life.

In our study there was no statically significant relation between the quality of life of participant and the crowding index. This in concordance with El Mashad, et al., 2016 [2] study as they found that there was no statically significant relation between asthma and room number, number of persons in bedroom and patient's bed.

In our study there is statically significant correlation between the socio-economic status and 
HRQoL of the asthmatic children and adolescent. This finding is in line with Mielck et al., 2014 [23] who found that HRQOL is affected by SES of the patient. This may be explained by the poor environmental exposures and the different access to health care services for different socio-economic class.

Conclusion: Asthma in children and adolescents significantly affect their HRQoL which in turn is influenced by sociodemographic factors as age, education and residency in addition to socioeconomic status of the family.

\section{References}

1- ALBEHANDY N.S., HUSSEIN H., AL FAISAL W., EL SAWAF E., E.S., WASFY A., ALSHAREEF N. and ALTHEEB A.A.S.: Risk Factors Analysis of Childhood Asthma in Dubai, UAE. International Journal of Preventive Medicine Research, 1 (4): 247-253, 2015.

2- EL-MASHAD G.M., MAHMOUD A.A. and ABDEL HAFEZ A.A.: The prevalence of bronchial asthma among primary school children in Menoufiya Governorate (ElBagour Center). Menoufia Med. J., 29: 89-94, 2016.

3- MANSOUR E.A.: Prevalence of bronchial asthma and its impact on cognitive functions and academic achievement among preparatory school children in Damietta Governorate, Egypt. The Journal of American Science, 10 (7): 119-127, 2014

4- HALIM W.B., KHALIL K.A., SOBHY S.A. and HASBALLAH S.A.: Prevalence of Bronchial Asthma Among Secondary Schools Students At Abu Khalifa VillageIsmailia Governorate, The Medical Journal of Cairo University, 81 (2): 19-24, 2013.

5- S`WINOGA M, KL OS M., MINISZEWSKA J. and ZALEWSKA-JANOWSKA A.: Health-related quality of life in dermatological and allergo-dermatological patients. Postep Derm Alergol., 29: 69-73, 2012.

6- ZHAO J., SHEN K., XIANG L., ZHANG G., XIE M., BAI J. and CHEN Q.: The knowledge, attitudes and practices of parents of children with asthma in 29 cities of China: A multi-center study. BMC Pediatrics, 13: 20, 2013.

7- CHULADA P.C., ARBES S.J. Jr., DUNSON D. and ZELDIN D.C.: Breast-feeding and the prevalence of asthma and wheeze in children: Analyses from the Third National Health and Nutrition Examination Survey, 1988-1994. J. Allergy Clin. Immunol., 111: 328-336, 2003.

8- UCHMANOWICZ B., PANASZEK B., UCHMANOWICZ I. and ROSIN'CZUK J.: Sociodemographic factors affecting the quality of life of patients with asthma. Patient Prefer Adherence, 10: 345-354, 2016.

9- WATSON J.P., COWEN P. and LEWIS R.A.: The relationship between asthma admission rates, routes of admission, and socioeconomic deprivation. Eur. Respir. J., 9: 2087-93, 1996.

10- EVERHART R.S. and FIESE B.H.: Asthma severity and child quality of life in pediatric asthma: Asystematic review. Patient Educ Couns, 75 (2): 162-168, 2009.

11- MOHANGOO A.D., De KONING H.J., MANGUNKUSUMO R.T. and RAAT H.: Health-Related Quality of Life in Adolescents with Wheezing Attacks. J. Adolesc. Health, 41 (5): 464- 471, 2007.

12- MOTAGHI-NEJAD M., SHAKERINEJAD G., CHERAGHI M., TAVAKKOL H. and SAKI A.: Quality of life in asthmatic patients. Int. J. Bioassays, 4: 3757-3762, 2015.

13- GONZALEZ-BARCALA F-J., De la FUENTE-CID R., TAFALLA M., NUEVO J. and CAAMAÑO-ISORNA F.: Factors associated with health-related quality of life in adults with asthma. A cross-sectional study. Multidiscip Respir Med., 7: 32, 2012.

14- APTER A.J., REISINE S.T., AFFLECK G., BARROWS E. and ZUWALLACK R.L.: The influence of demographic and socioeconomic factors on health-related quality of life in asthma. J. Allergy Clin. Immunol., 103: 72-8, 1999.

15- EL-GILANY A., EL WEHADY A. and EL WASIFY M.: Updating and validation of the socioeconomic status scale for health research in Egypt. East Mediterranean Health Journal, 18 (9): 962-8, 2012.

16- ABDEL HAI R., TAHER E. and ABDEL FATTAH M.: Assessing validity of the adapted Arabic Paediatric Asthma Quality of Life Questionnaire among Egyptian children with asthma. Eastern Mediterranean Health Journal, 16 (3): 274-280, 2010

17- JUNIPER E.F., GUYATT G.H., FEENY D.H., FERRIE P.J., GRIFFITH L.E. and TOWNSEND M.: Measuring quality of life in children with asthma. Qual Life Res., 5 (1): 35-46, 1996.

18- MIADICH S.A., EVERHART R.S., BORSCHUK A.P. WINTER M.A. and FIESE B.H.: Quality of Life in Children with Asthma: A Developmental Perspective. Journal of Pediatric Psychology, 40 (7): 672-679, 2015.

19- MATSUNAGA N.Y., RIBEIRO M.A., SAAD I.A., MORCILLO A.M., RIBEIRO J.D. and TORO A.A.: Evaluation of quality of life according to asthma control and asthma severity in children and adolescents. J. Bras Pneumol., 41 (6): 502-508, 2015.

20- AL-GEWELY M.S., EL-HOSSEINY M., ABOU ELEZZ N.F., ELGHONEIMY D.H. and HASSAN A.M.: Healthrelated quality of life in childhood bronchial asthma. Egypt J. Pediatr. Allergy Immunol., 11 (2): 83-93, 2013.

21- FERREIRA L.N., BRITO U. and FERREIRA P.L.: Quality of life in asthma patients. Rev. Pol. Pneumol., 16: 23-55, 2010.

22- NORBÄCK D., LU C., WANG J., ZHANG Y., LI B., ZHAO Z., HUANG C., ZHANG X., QIAN H., SUN Y., SUNDELL J. and DENG Q.: Asthma and rhinitis among Chinese children - Indoor and outdoor air pollution and indicators of socioeconomic status (SES). Environment International, 115: 1-8, 2018.

23- MIELCK A., VOGELMANN M. and LEIDL R.: Healthrelated quality of life and socioeconomic status: Inequalities among adults with a chronic disease. Health Qual Life Outcomes, 12: 58, 2014. 


\section{العوامل الديموغرافية والاجتماعية والاقتصادية وإية

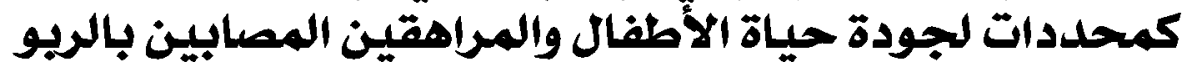

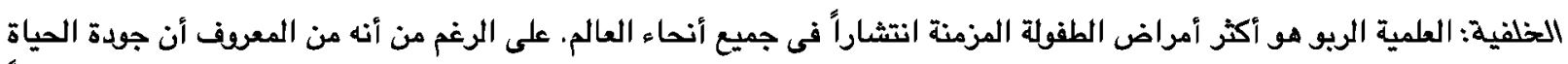

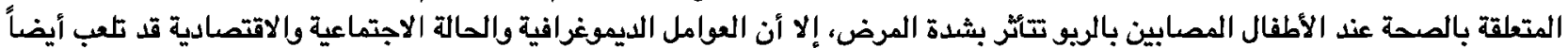
لدواً هـاماً.

الهدف من الدراسة: دراسة تأثير العوامل الاجتماعية والديموغرافية والاقتصادية على جودة الحياة في الأطفال والمراهقين المصابين بالربو.

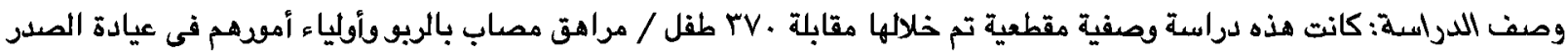

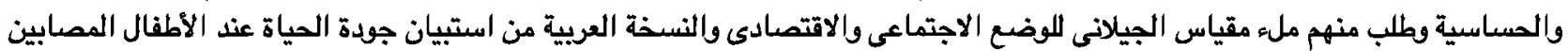
بالريو ثم تم حساب إجمالى الدرجات.

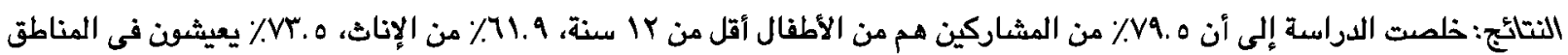

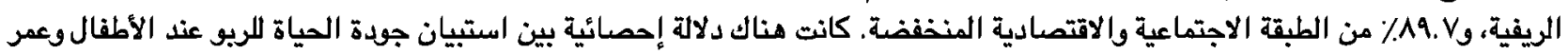

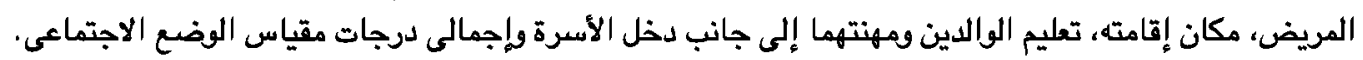
الخلاصة: يمكن اعتبار الوضع الديموغرافى والاجتماعى والاتتصادى مصددات مستقلة لجودة الصياة فى الأطفال والمراهقين المصابين 